\title{
The performance analysis of organic rankine cycles combined CCHP system
}

\author{
Tong Zhu*, Tao Zhang, Naiping Gao \\ School of Mechanical Engineering, Tongji University, No. 1239, Siping Road, Shanghai 200092, China
}

\begin{abstract}
In the past few years, Distributed Energy Resources (DER) have been received increasing attention all over the world, on the account of benefits in environment and economy as an energy system. Combined Cooling, Heating, and Power (CCHP) system as a general DER mode is an effective solution to save energy and reduce the pollution, while ORC (Organic Rankine Cycle) is an effective means to Recovery of waste heat power generation. In this paper, a new system combined CCHP and ORC is described. A Non-Liner Programming (NLP) model is established to optimize the equipment like Internal Combustion Engine (ICE), heat recovery system, gas boiler, absorption chiller, heat exchangers and ORC system. The economic efficiency, energy efficiency, environmental benefits are taken into account. Because the ORC system is not mature, a discussion about the changing of ORC system price is made. The result shows the price of ORC has dramatic influence to the capacity of ORC in the combined system. But it has little influence to other equipment capacity. Added an ORC system to CCHP is more environmentally friendly.
\end{abstract}

Keywords: CCHP, ICE, ORC, optimization, NLP

\section{Introduction}

Energy shortage and environmental pollution are the prime social issues in all of the countries. As the rapid growth of world economic, the more energy consumption is need. Therefore, it is important to address the conflict between insufficient energy supply and energy consumption. In recent years, the utilization of technologies for renewable energy sources is booming, however, the costs and efficiency is primary obstacles for the development of renewable energy. Furthermore, the intermittent of renewable energy is not possible to eliminate. CCHP (combined cooling, heating and power) system is a attracted more attention due to the high conversion efficiency, environmental benefits and cascaded utilization of energy [1].

The Internal Combustion Engine (ICE) is a most commonly used Power Generation Unit (PGU) compared with other PGUs like turbine, fuel cell and photovoltaic in CCHP system. The net power generation efficiency of ICE is about 30\% 40\%. The conversion efficiency means the primary energy to total net power and heat in CCHP can be up to 70\% 80\%, which is higher than the traditional independent energy system [2]. However, maintain the efficiency of CCHP need the supply of energy is matching the users' demands. If not, the system must be unsteady or waste the redundant energy.

Energy consumption characteristics of four typical commercial buildings in Japan was analysed and the energy consumption was simulated adopted four PGUs, the results show that the prior order for PGU technologies is gas turbines, gas engines, diesel engines and fuel cells for hotels, fuel cells, gas engines and gas turbines, diesel engines for hospitals, fuel cells, diesel engines, gas engines and gas turbines for stores, diesel engines, fuel cells, gas engine and gas turbine for offices [3]. The sizing prime movers for CCHP systems operating at full load to satisfy a facility's electric load, the process applied ratios of conversion factors to imported electricity to fuel consumed, and three criteria Operational Cost (OC),

* Manuscript received October 15, 2015; revised January 18, 2016.

Corresponding author. Tel.: +86-13816387430; E-mail address: zhu_tong@tongji.edu.cn.

doi: $10.12720 /$ sgce.5.1.1-8 
Carbon Dioxide Emissions (CDE), and Primary Energy Consumption (PEC) [4]. A hybrid electricthermal load operation strategy which can make a choice of current operating mode between following the electric load and following the thermal load is proposed [5]. No matter what operating strategy for CCHP system, we still cannot match the needs and supplies perfectly because the random variation of energy demands.

For the supplies of CCHP is insufficient, adding extra energy (from additional combustion boiler or power gird) is a common methods to address this problems. But when there is too much supplies of energy, the available treatments are selling electricity to power grid or converting thermal/cooling energy by electric heater/chiller. A conceptual scheme and procedure based on thermo-economics is presented to design and optimization of a CCHP system, which a hybrid cooling subsystem is utilized to fulfil the requirement of users [6]. Similarly, to recover to excess thermal energy, the practical engineering projects have two methods: the thermal storage tank or convert thermal energy to electricity by some power generation systems. There are several systems like Organic Rankine Cycles (ORC), Kalina cycle, stirling engine and thermoelectric power generation. ORC systems is wide application nowadays, which uses organic fluid with low boiling points and can use various types of heat source including waste heat [7], solar energy [8], geothermal energy [9], biomass energy [10] etc. The key points of ORC research is the choice of expanders and working fluids and different scale of ORC systems and various heat sources need different types of expanders and working fluids. To effectively utilize low and medium temperature energy, a reviews for selections of expanders and working fluids' category and thermodynamic and physical properties, expanders have two types like axial velocity type and volume type [11]. Fang et al. configured a CCHP-ORC system, and then configuration and operation is optimized for a hypothetical hotel in Beijing. The primary energy consumption, the carbon dioxide emissions and the operation cost of proposed CCHP-ORC system are better than the conventional CCHP system obvious. [12]

There are many researches on engines coupled ORC systems. The heat recovery of diesel engine for electric power generation used Kalina cycle and ORC systems, the comparison between them can concludes Kalina cycle require a very high pressure to obtain high performance than ORC system [13]. A system with ICE bottoming with ORC systems is investigated and results show that a $12 \%$ increase in the overall efficiency can be achieved with respect to the engine with no bottoming [14]. A experimental study on ORC system with single-screw expander for waste heat recovery from exhaust of diesel engine, and the maximum of the power output is $10.38 \mathrm{~kW}$ and the biggest ORC efficiency and overall system efficiency are respectively $6.48 \%$ and $43.8 \%$ [15]. There have some research on ORC coupled with CCHP yet. Like Mago et.al analysed energetic, economic and environmental performances of CHP-ORC in different climate zones [16], [17]. However, in that paper there is only a chosen ORC system with special working fluid and fixed efficiency. In reality, the fixed efficiency is impossible obviously. The utilization of ORC will impact the pressure of exhaust gas of PGU in CCHP, and the efficiency of CCHP is variable when uses ORC system. In this paper, firstly we introduce different scale of ICE with different waste heat energy and temperature. Then we select different working fluids for different waste heat characteristics. At last, we compare different coupled styles of ICE-ORC and give a more suitable style.

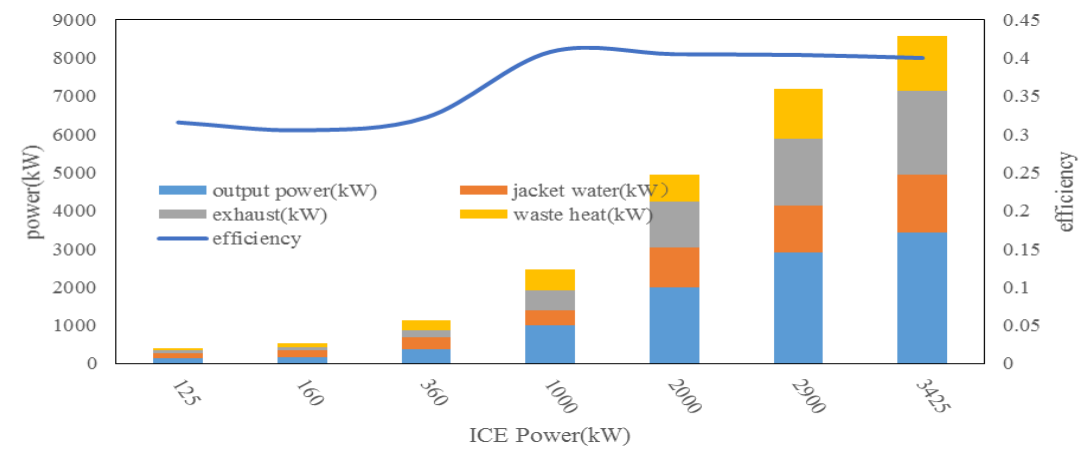

Fig. 1. The waste heat and efficiency of ICEs. 


\section{Description of ICE-ORC System}

The waste heat of ICE includes the energy of jacket water and exhaust gas. In this paper, we introduce a series of available ICEs in reality to get different grade of waste heat. As show in Fig. 1, there is seven different scale of ICEs from 125 to $3425 \mathrm{~kW}$. The efficiency of ICE is about $40 \%$ when the capacity is above $1000 \mathrm{~kW}$ and is below $35 \%$ when the capacity is below $1000 \mathrm{~kW}$. The quantity of jacket water are far different and the quantity is growth as the capacity is increase. When the capacity is in size the quantity of jacket water is more than waste heat, it's the opposite when the capacity is large as show Fig. 2 .

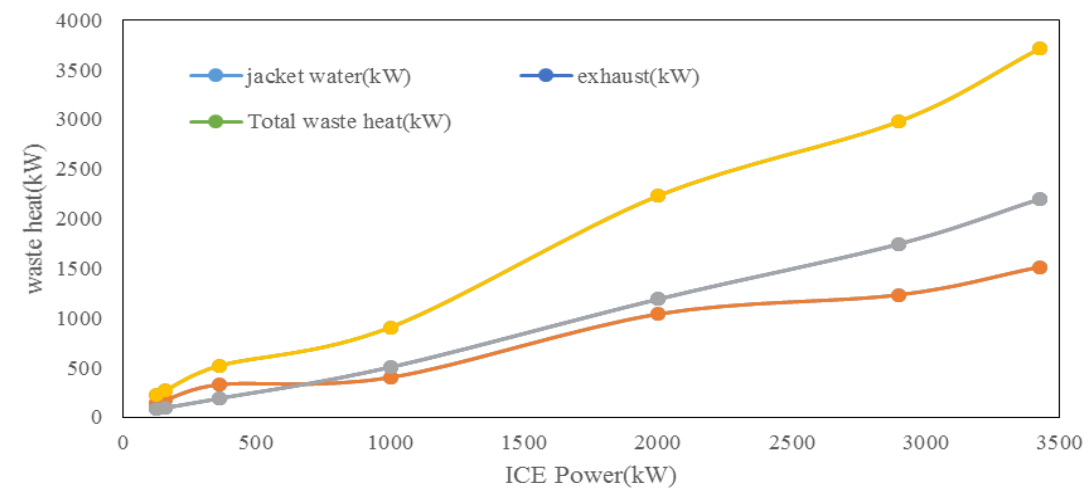

Fig. 2. The quantity of ICEs' waste heat.

Vaja shows three scheme of ORC configurations assumed for ICE which is ORC simple driven by engine exhaust gases, exhaust and jacket water and regenerated ORC which be driven by exhaust gases [14]. There are always several modes to recover heat to power generation, the most common mode is only utilize the exhaust heat for the operation of ORC system. Obviously, ORC system with preheat by jacket water has higher combined efficiency. In this paper, we innovatively employ thermal oil cycle instead of jacket water cycle. On this way, we could get higher temperature at atmosphere pressure. The thermal oil is divided into two fluid in shunt which one fluid will get more energy with exhaust heat exchanger and other is used to preheat the working fluid. The coupled ICE with ORC is showed in Fig. 3.

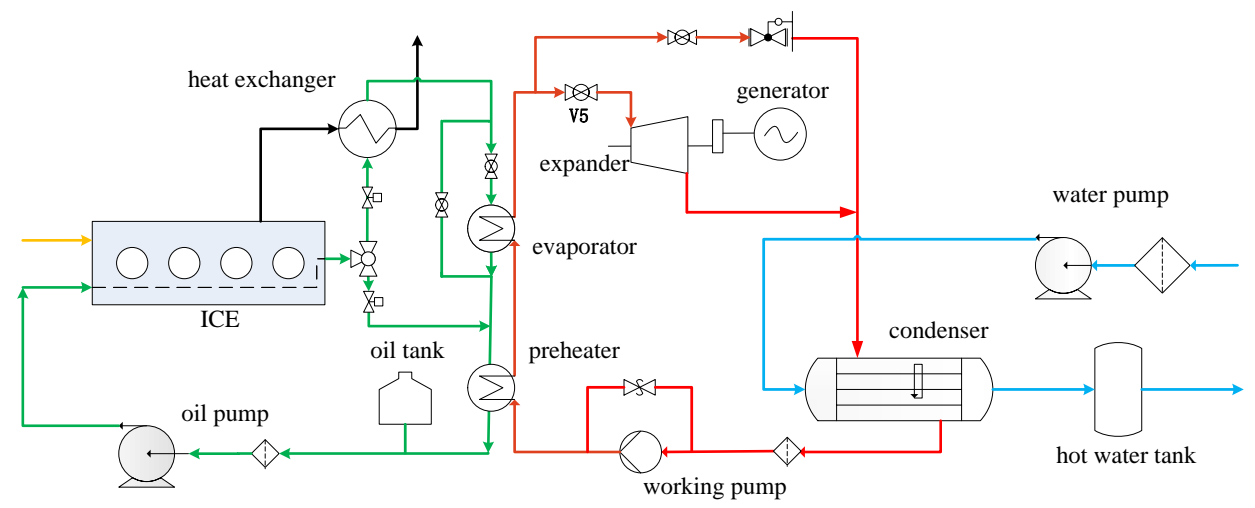

Fig. 3. Configuration and processes of simple ICE-ORC.

\section{The Model of CCHP-ORC}

This section introduces the configuration of CCHP-ORC system as can be seen in Fig. 4, and then a mathematical optimization model is constructed to design and analysis the overall system. 
The traditional CCHP system general is designed for a user who has energy demands of electricity, cooling and heating. A simple CCHP system usually includes PGU, auxiliary boiler, absorption chiller, heat exchanger and utility electricity. The PGU offers electricity and thermal energy simultaneously. If the electricity demand is more than the supply of PGU, the utility electricity provides surplus demand. In some situations the redundant power of CCHP could be sold to the grid too. The coupled of CCHP-ORC means a transformation technology of heat to power added in system as show in Fig. 4. If the thermal requirement is more than supply, the auxiliary boiler will offer extra quantity of heat. Otherwise the redundant of thermal energy could be converted to electricity by ORC system.

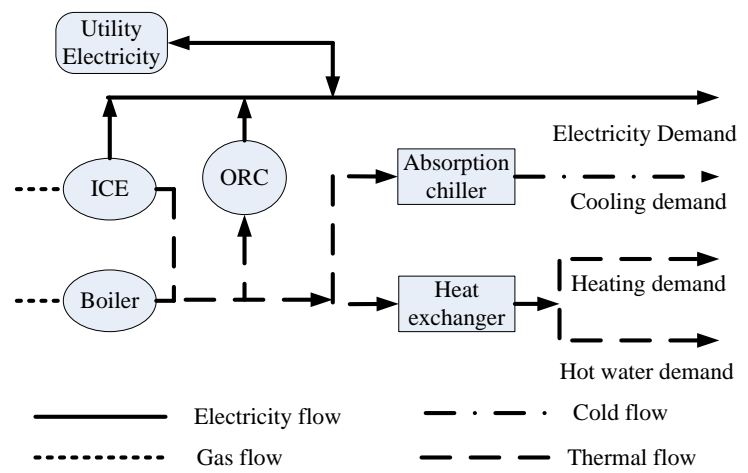

Fig. 4. Description of CCHP-ORC system.

A mathematical optimization model is constructed to get the capacity of each equipment and evaluation parameters of system by translate this problem to a NLP (non-linear programming) problem. The objective function is to minimize the total annual cost of the system for the investors.

$$
\text { Min } C_{\text {total }}=C_{\text {capital }}+C_{O \& M}+C_{\text {fuel }}+C_{\text {epur }}
$$

where:

$C_{\text {total }}=$ total annual cost (yuan)

$C_{\text {capital }}=$ devices' investment of system (yuan)

$C_{O \& M}=$ cost of operation and maintenance (yuan)

$C_{\text {fuel }}=$ cost of purchase fuel (yuan)

$C_{e p u r}=$ cost of purchase electric power from gird (yuan)

$$
\begin{gathered}
C_{\text {capital }}=\sum_{\text {tech }} I_{\text {tech }} \cdot \text { Cap }_{\text {tech }} \cdot \frac{I}{1-(1+I)^{-L_{\text {tech }}}} \\
C_{O M}=\sum_{\text {tech }} O M_{\text {tech }} \cdot \sum_{m} \sum_{h r} E_{\text {tech }, m, h r} \\
C_{\text {fuel }}=\sum_{m} \sum_{h r} V_{\text {gas }, m, h r} \cdot P_{\text {gas }, m, h r} \\
C_{\text {epur }}=\sum_{m} \sum_{h r} E_{\text {epur }, m, h r} \cdot p_{\text {epur }, m, h r}
\end{gathered}
$$

where:

Inv $v_{\text {tech }}=$ total annual cost (yuan)



$I=$ discout rate (-)

$L t_{\text {tech }}=$ lifetimes of different equipment (year) 
$O M_{\text {tech }}=$ different devices operation equipment $(\mathrm{yuan} / \mathrm{kW})$

$E_{\text {tech, } m, h r}=$ hourly load of different equipment $(\mathrm{kW})$

$V_{g a s, m, h r}=$ hourly gas consumption $\left(\mathrm{m}^{3}\right)$

$P_{\text {gas, } m, h r}=$ hourly gas purchasing price $\left(\mathrm{yuan} / \mathrm{m}^{3}\right)$

$E_{\text {epur, } m, h r}=$ hourly electric consumption $(\mathrm{kWh})$

$P_{\text {epur, } m, h r}=$ hourly electric purchasing price (yuan $/ \mathrm{kWh}$ )

The main constraints include inequality and equality equations. The balance of energy demands and supply must be achieved at any point.

$$
\begin{gathered}
E_{\text {des,out }, m, h r}+E_{\text {epur }, m, h r}+E_{\text {ORC }, m, h r} \geq E_{\text {demand }, m, h r} \\
C_{\text {des,out }, m, h r} \geq C_{\text {demand }, m, h r} \\
H_{\text {des,out }, m, h r} \geq H_{\text {demand }, m, h r}
\end{gathered}
$$

where:

$E_{\text {des, out, } m, h r}=$ hourly output power of ICE system (kW)

$E_{\text {demand, } m, h r}=$ hourly demand of power $(\mathrm{kW})$

$E_{O R C, m, h r}=$ hourly output of ORC system $(\mathrm{kW})$

$C_{\text {des, out }, m, h r}=$ hourly output of cooling $(\mathrm{kW})$

$C_{\text {demand, out, } m, h r}=$ hourly demand of cooling $(\mathrm{kW})$

$H_{\text {des, out }, m, h r}=$ hourly output of heating $(\mathrm{kW})$

$H_{\text {demand, out, } m, h r}=$ hourly demand of heating $(\mathrm{kW})$

There still have a lot of constraints in the energy generation and conversion sections which didn't present here.

\section{Case Study}

In this paper, we consider a hotel in Shanghai about $9600 \mathrm{~m}^{2}$. The building loads are estimated by DeST software, so we could obtain the whole year's energy demand at 8760 hours. It's obviously optimizing every hours in the years for the CCHP-ORC system has a huge amount of calculation. We assume energy day in each month has some load demands at first day of that month, then the computing number of hours reduced from 8760 to 288 . The load demands in representative day in Jan. 1 and Jul.1 are shown in Fig. 5.

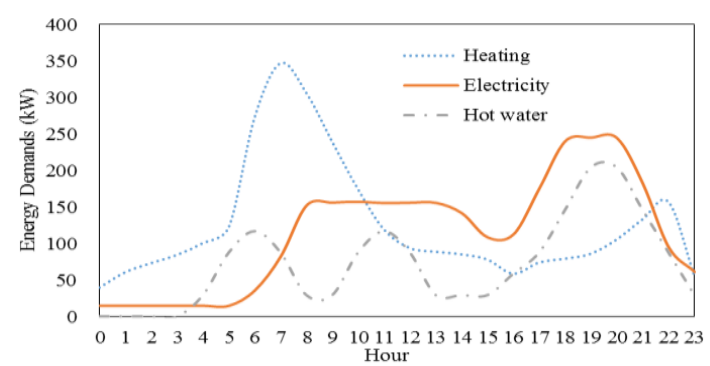

(a) The loads in Jan. 1

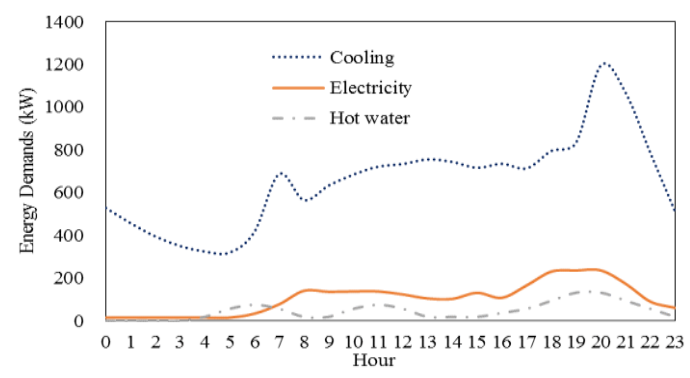

(b) The loads in Jul. 1

Fig. 5. The loads of cooling, heating, electric power and domestic hot water.

Each equipment of different technological, economical data like investment, operation and maintenance, efficiency and lifetimes are showed in Table 1 [18]-[20].

The optimization result of CCHP-ORC system when the price of ORC system is $9000 \mathrm{yuan} / \mathrm{kW}$ shows in Table 2. We can conclude that the capacity of ORC is not the main power generation unit. Even 
without ORC system, the capacity of other equipment is almost some with ORC system.

Table 1. The technological and economic data of energy generation technologies

\begin{tabular}{llllll}
\hline \multirow{2}{*}{ Technology } & $\begin{array}{l}\text { Investment, } \\
\text { yuan/kW }\end{array}$ & $\begin{array}{l}\text { O\&M cost, } \\
\text { yuan/kWh }\end{array}$ & Efficiency & Lifetime \\
\cline { 3 - 5 } (year)
\end{tabular}

Table 2. The optimization results

\begin{tabular}{|c|c|c|}
\hline Equipment of CCHP-ORC & Capacity with ORC $(\mathrm{kW})$ & Capacity without ORC $(\mathrm{kW})$ \\
\hline internal combustion engine & 182 & 179 \\
\hline boiler & 974 & 978 \\
\hline absorption chiller & 1198 & 1198 \\
\hline heat exchanger & 437 & 437 \\
\hline orc & 8 & 0 \\
\hline
\end{tabular}

The ORC system is still not mature enough inexpensive acquire. So we consider the influence of price of ORC system to the capacity of ORC in optimization process. As show in Fig. 6, the price of ORC has great influence to the capacity of ORC system. When the price is above $14000 \mathrm{yuan} / \mathrm{kW}$, ORC is too expensive to use in CCHP system. As the increase of ORC price, the capacity of ORC is become small. As the optimization result, the consumption of gas is more and consumption of electricity is less.

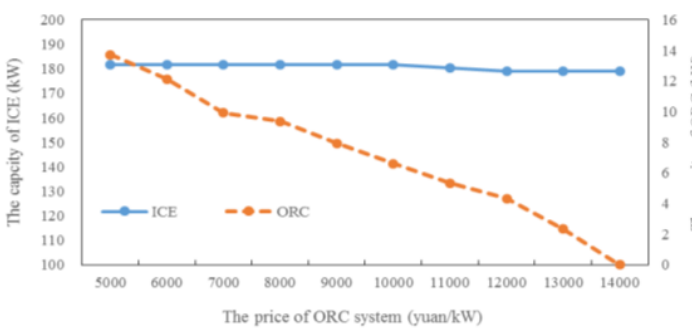

(a) The influence to capacity

Fig. 6. The influence of ORC price.

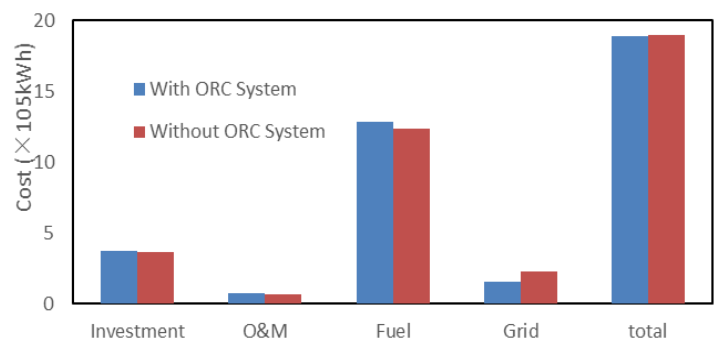

(a) The price of ORC is $9000 \mathrm{yuan} / \mathrm{kW}$

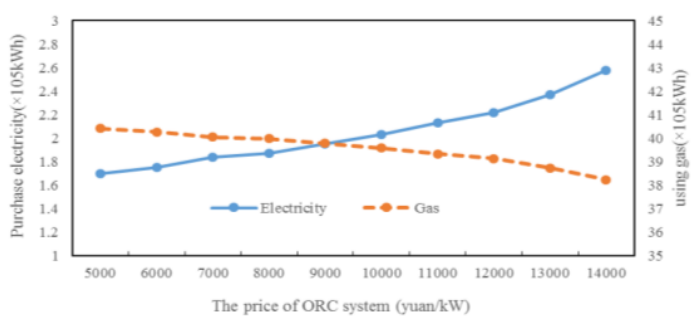

(b) The influence to energy consumption

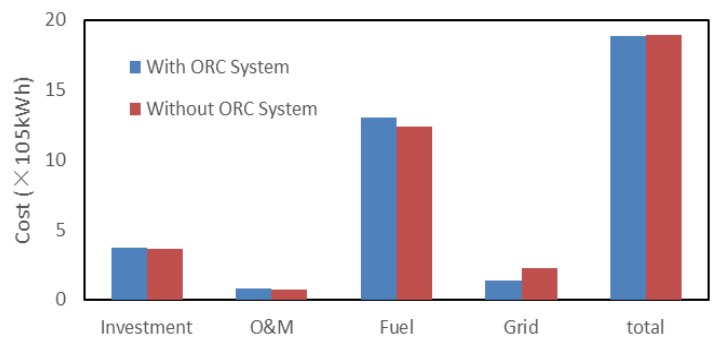

(b) The price of ORC is 5000 yuan $/ \mathrm{kW}$

Fig. 7. The influence of ORC price to system cost.

The cost of system decides whether or not have potential to promote practical use. In Fig. 7, the different of optimization cost result is showed when the price of ORC system is 5000 and 9000 yuan/kW. The result shows the total cost of system is almost no change. The investment of system has a little raise when the system have ORC. There is a decline in purchase electricity from grid compared to operation 
and maintenance cost. Because ORC system converts thermal energy to electricity, so the consumption of fuel is increase with ORC system.

Table 3 shows the important evaluation criterion of CCHP system with and without ORC. We can get that there is little influence to the primary energy consumption and Primary energy ratio. It has some conclusion as above. But there is more environment friendly compared to the system without ORC.

Table 3. The optimization results

\begin{tabular}{|c|c|c|}
\hline Items & With ORC System & Without ORC System \\
\hline $\begin{array}{c}\text { Primary energy consumption } \\
(\times 105 \mathrm{kWh} / \text { year })\end{array}$ & 46.75 & 47.47 \\
\hline Primary energy ratio & 0.75 & 0.74 \\
\hline $\mathrm{CO}_{2}$ emissions (t/year) & 84.8 & 88.3 \\
\hline NOx emissions (t/year) & 1.17 & 1.33 \\
\hline
\end{tabular}

In this paper, an integrated design and operational strategy model has been developed using a nonlinear programming for CCHP system and CCHP-ORC system. The price of ORC system has been discussed for a better capacity of equipment and a lower total annual cost for optimization. The compared between CCHP and CCHP-ORC system is discussed. Those conclusion lead to the following:

1. There is barely influence to the capacity of other equipment capacity with ORC system.

2. The total cost of system almost doesn't decline with ORC system largely because of the increase of gas consumption.

3. Added ORC system to recover extra energy to electricity has more environmental benefits. The primary energy consumption and primary energy ratio is influenced very little.

\section{Acknowledgements}

The authors would like to acknowledge the financial support from The National Fundamental Research Program 973 project (2014CB249200) "Research on the stability of complex energy system integrated natural gas and renewable energy".

\section{References}

[1] Wang JJ, Fu C, Yang K, Zhang XT, Shi GH, Zhai J. Reliability and availability analysis of redundant BCHP (building cooling, heating and power) system. Energy, 2013; 61:531-540.

[2] Fang F, Wang QH, Shi Y. A novel optimal operational strategy for the CCHP system based on two operating modes. Ieee Transactions on Power Systems, 2012; 27:1032-1041.

[3] Ruan YJ, Liu QR, Zhou WG, Firestone R, Gao WJ, Watanabe T. Optimal option of distributed generation technologies for various commercial buildings. Appl. Energ., 2009; 86:1641-1653.

[4] Mago PJ, Luck R. Prime mover sizing for base-loaded combined heating and power systems. In: Proc. of the Institution of Mechanical Engineers Part a-Journal of Power and Energy, 2012; 226:17-27.

[5] Mago PJ, Chamra LM. Analysis and optimization of CCHP systems based on energy, economical, and environmental considerations. Energy and Buildings, 2009; 41:1099-1106.

[6] Cardona E, Piacentino A. Optimal design of CHCP plants in the civil sector by thermoeconomics. Applied Energy, 2007; 84:729-748.

[7] Kaşka Ö. Energy and exergy analysis of an organic Rankine for power generation from waste heat recovery in steel industry. Energy Conversion and Management, 2014; 77:108-117.

[8] Jing L, Gang P, Jie J. Optimization of low temperature solar thermal electric generation with organic rankine cycle in different areas. Appl. Energ., 2010; 87:3355-3365.

[9] Vetter C, Wiemer HJ, Kuhn D. Comparison of sub- and supercritical organic rankine cycles for power generation from lowtemperature/low-enthalpy geothermal wells, considering specific net power output and efficiency. Appl. Therm. Eng, 2013; 51:871-879.

[10] Taljan G, Verbic G, Pantos M, Sakulin M, Fickert L. Optimal sizing of biomass-fired organic rankine cycle chp system with heat storage. Renewable Energy, 2012; 41:29-38. 
[11] Bao J, Zhao L. A review of working fluid and expander selections for organic Rankine cycle. Renewable \& Sustainable Energy Reviews, 2013; 24:325-342.

[12] Fang F, Wei L, Liu J, Zhang J, Hou G. Complementary configuration and operation of a CCHP-ORC system. Energy, 2012; 46:211-220.

[13] Bombarda P, Invernizzi CM, Pietra C. Heat recovery from diesel engines: a thermodynamic comparison between kalina and ORC cycles. Appl. Therm. Eng., 2010; 30:212-219.

[14] Vaja I, Gambarotta A. Internal Combustion Engine (ICE) bottoming with Organic Rankine Cycles (ORCs). Energy, 2010; 35:1084-1093.

[15] Zhang YQ, Wu YT, Xia GD, Ma CF, Ji WN, Liu SW, Yang K, Yang FB. Development and experimental study on organic Rankine cycle system with single-screw expander for waste heat recovery from exhaust of diesel engine. Energy, 2014; 77:499-508.

[16] Mago PJ, Hueffed A, Chamra LM. Analysis and optimization of the use of CHP-ORC systems for small commercial buildings. Energy and Buildings, 2010; 42:1491-1498.

[17] Mago PJ, Luck R. Evaluation of the potential use of a combined micro-turbine organic rankine cycle for different geographic locations. Appl. Energ., 2013; 102:1324-1333.

[18] Zhou Z, Liu P, Li Z, Ni W. An engineering approach to the optimal design of distributed energy systems in China. Appl Therm. Eng., 2013; 53:387-396.

[19] Ren HB, Zhou WS, Nakagami K, Gao WJ, Wu QO. Feasibility assessment of introducing distributed energy resources in urban areas of China. Appl. Therm. Eng., 2010; 30:2584-2593.

[20] Li CZ, Shi YM, Huang XH. Sensitivity analysis of energy demands on performance of CCHP system. Energy Conversion and Management, 2008; 49:3491-3497. 